\title{
Kuvitteellisia periferioita
}

Artikkeli tarkastelee nenetsikirjailija Anna Nerkagin pienoisromaaneja Nogosuvun Aniko (1976) ja Valkea jäkälä (1996) sekä venäläisen elokuvaohjaaja Vladimir Tumajevin näiden teosten pohjalta ohjaamaa elokuvaa Valkea jäkälä (2014). Lähestyn teoksia kysymällä, kuinka niissä kuvataan arktista tundraa tilana ja kuinka teoksissa kuvattu perifeerinen tila esitetään suhteessa valtakeskuksiin. Artikkelin tärkeimpinä teoreettisina viitekehyksinä toimivat tilan teoriat sekä jälkikolonialistinen teoria. Nerkagin teoksissa tundra näyttäytyy muusta maasta irrallisena alkuperäiskansan toimintaympäristönä, joka kytkeytyy sekä nenetsien historiaan että näiden suhteeseen ei-inhimillisen luonnon kanssa. Erityisesti Valkean jäkälän voi nähdä myös kritisoivan yhteiskunnan tapaa laiminlyödä alueen asioiden hoitoa. Tumajevin elokuva puolestaan nojaa venäläisessä kulttuurissa vallitseviin käsityksiin arktisesta tundrasta ja heijastaa myös Venäjän 2000-Iuvulla aktivoitunutta tarvetta profiloitua arktisena suurvaltana.

Eeva Kuikka

Venäjän arktisen alueen alkuperäiskansat joutuivat neuvostoaikoina uudenlaisen ongelman eteen: odotusten vastaisesti kaupunkien sisäoppilaitoksissa koulutetut alkuperäiskansojen nuoret halusivat jäädä asutuskeskuksiin, ja alkuperäiskansojen omat yhteisöt, kielet ja kulttuurit uhkasivat kuolla vanhempien sukupolvien mukana (Slezkine 1994, 349-350) ${ }^{1}$. Kasvot näille nuorille antoi nenetsikirjailija Anna Nerkagin pienoisromaanin Nogo-suvun Aniko (Aniko iz roda Nogo, 1976) päähenkilö Aniko. Urbanisoituneessa ja globalisoituneessa nykymaailmassa alkuperäiskansoihin kuuluvien nuorten tasapainoilu oman kulttuurin ja valtakulttuurin välillä on edelleen ajankohtainen kysymys (Ziemer 2011, Ulturgasheva 2012, Huusko 2018). Tästä kielii myös se, että Nerkagin 1970-luvulla julkaistu romaani sekä sen 1996 ilmestynyt jatko-osaa muistuttava pienoisromaani Valkea jäkälä (Belyj Jagel) filmatisoitiin romaaneja mukaillen vuonna 2014. 
Nerkagin kirjat ja niiden pohjalta tehty filmatisointi käsittelevät alkuperäiskansojen kannalta sosiaalisesti tärkeää aihetta ja nostavat samalla esille tilallisuuden ulottuvuuden ja sen kulttuurisen merkitystason. Nuorten tehdessä päätöksiä asuinpaikkansa suhteen rakentuu pienoisromaanien ja elokuvien tapahtumapaikka, Venäjän arktinen tundra, perifeerisyyden kautta vastakkaiseksi suhteessa hallinnollisiin keskuksiin. Tässä vastakkainasettelussa tundra rinnastuu alkuperäiskansan elintapoihin ja perinteeseen, kun taas kaupunkialueet rakentuvat suhteessa venäläiseen valtakulttuuriin ja nykyaikaan. Kysyn tässä artikkelissa, millaista kuvaa Nerkagin teokset ja niitä mukaileva filmatisointi rakentavat Venäjän arktisesta tundrasta tilana ja millaisena perifeerisen tundran ja valtakeskusten välinen suhde esitetään. Tarkastelen myös sitä, eroavatko alkuperäiskansaan kuuluvan kirjailijan ja alkuperäiskansan ulkopuolelta tulevan elokuvaryhmän luomat tundran kuvaukset toisistaan. Aloitan artikkelin esittelemällä lyhyesti Nerkagin teosten taustalla olevan historiallisen kontekstin sekä kaunokirjalliset teokset ja Tumajevin elokuvan, minkä jälkeen luon katsauksen artikkelissa hyödynnettyihin tutkimusteorioihin, tilan tutkimukseen (geocriticism) ja jälkikolonialismiin. Lähestyn artikkelissa käsiteltäviä teoksia suhteessa perifeerisyyteen, tundran ja muun maan väliseen dynamiikkaan, ruumiillisuuteen ja ei-inhimilliseen luontoon liittyviin kysymyksiin.

Anna Nerkagi (s. 1952) kuuluu etniseltä taustaltaan nenetseihin, joiden asuma-alueet levittäytyvät Luoteis-Venäjän Kuolan niemimaalta aina Taimyrin niemimaalle asti. Lukumäärältään nenetsit ovat Venäjän suurin pohjoinen alkuperäiskansa. Suurin osa nenetseistä on tundranenetsejä, joiden pääasiallinen elinkeino on poronhoito. Siperian nenetsien ensimmäiset kohtaamiset venäläisten kanssa tapahtuivat 1500-luvulla kasakkojen vallattua Luoteis-Siperian ja alistettua paikalliset alkuperäiskansat maksamaan luontaisveroa muuntaen Siperian Venäjän keisarikunnan siirtomaaksi (Homitš 1966, 42-46; Golovnev 1995, 89-91). Bolševikit katsoivat vapauttaneensa alueen tsaarinaikaisesta siirtomaastatuksesta, mutta myös neuvostovalta kiinnostui 1920-luvulla alueen taloudellisesta hyödyntämisestä. 1930-luvulle tultaessa kiihtyi poliittinen halu jalkauttaa alkuperäiskansojen parissa sosiaalisia uudistuksia kuten kollektivisaatiota. Pohjoisen ja arktisen alueen luonnonvarojen hyödyntäminen johti sekä venäläisväestön lisääntymiseen alkuperäiskansojen kotiseudulla että vakaviin ympäristöongelmiin. (Slezkine 1994, 187-196, 338; Bruno 2016.) Myös venäläinen koulujärjestelmä, jonka piiriin alkuperäiskansaperheiden lapset neuvostoaikana otettiin, vaikutti pohjoisten alkuperäiskansojen elämään. Oleskelu pääasiassa venäjänkielisissä sisäoppilaitoksissa erossa omasta kulttuurista johti venäjän kielen aseman vahvistumiseen arktisella alueella ja alkuperäiskansakielien osaamisen heikentymiseen (Forsyth 1992, 388-389). Myös opetushenkilökunnan asenne alkuperäiskansalapsia kohtaan oli usein rasistinen ja oppilaiden etnistä taustaa halveksuva (Ljarskaja 2006). Kysymys alueen koulutuspolitiikasta ei ole kuitenkaan täysin mustavalkoinen, ja esimerkiksi Alexia Bloch (2003) näkee sen tarjonneen alkuperäiskansojen naisille näiden perinteistä roolia laajemmat mahdollisuudet toteuttaa itseään.

Neuvostoliiton arktisen alueen historiaa voidaan tarkastella asuttajakolonialismin puitteissa. Kyseessä oli prosessi, jossa ei-alkuperäinen valtaväestö syrjäytti alkuperäiskansojen oikeuden näiden asuttamiin maa-alueisiin ja otti haltuunsa sekä alueet että niiden sisältämät luonnonvarat (vrt. Wolfe 2006). Erityisesti keisarillista Venäjää on tarkastelu imperialistista kolonisaatiopolitiikkaa harjoittaneena suurvaltana. Neuvostoliitto sen sijaan mielsi itsensä dekolonialistisena projektina, joka koki vapauttaneensa alkuperäiskansat tsaarinaikaisista kolonialistisista käytännöistä. Kuten Lilia Boliachevets ja Ivan Sablin (2016, 387-388) osoittavat, moni alkuperäiskansojen jäsenistä näki Neuvostoliiton tässä valossa. Tämä näkyy myös joidenkin alkuperäiskansoista nousevien kirjailijoiden, esimerkiksi Vladimir Kojanton 
ja Nelja Suzdalovan, teksteissä. Boliachevets ja Sablin (ibid., 393-396) toteavat kuitenkin, että jälkikolonialistisen terminologian soveltamisen hankaluudesta huolimatta alkuperäiskansat olivat Neuvostoliitossa kulttuurisesti toiseutetussa ja alistetussa asemassa. Tämä johti niin "symboliseen ja diskursiiviseen väkivaltaan" (ibid., 395) kuin ylhälätä asetettuun keskusjohtoiseen valta-asetelmaan sekä alkuperäiskansojen asuinalueiden taloudelliseen hyödyntämiseen. Myös Sanna Turoma ja Maxim Waldstein (2013) näkevät Neuvostoliiton tarkastelun jälkikolonialistisessa viitekehyksessä tärkeänä. He korostavat kuitenkin tarvetta tulkita Neuvostoliiton tilannetta läntistäjälkikolonialistista keskustelua leimaavien valmiiden ja usein binääristen mallien ulkopuolelta käsin.

Neuvostoliiton ja myöhemmin 1990-luvun arktisen alueen alkuperäiskansojen tilanne näkyykin monin tavoin Anna Nerkagin teoksissa. Esimerkiksi autobiografisista elementeistä huolimatta Nerkagin esikoisromaanin Nogo-suvun Anikon voi nähdä edustavan laajempaa alkuperäiskansojen edustajien sukupolvikokemusta. Tundralle äitinsä ja pikkusiskonsa kuoleman takia palannut Aniko on luonut oman elämänsä kaupunkiin ja vierastaa elämää tundralla, mutta yksin jäänyt isä ja muut kyläläiset odottavat Anikon jäävän kotiseudulleen ja lunastavan paikkansa Nogo-suvun viimeisenä jatkajana. Siinä missä Anikon tarinassa käsitellään kotiinpaluun herättämiä tunteita palaajan näkökulmasta, Valkea jäkälä kuvaa sitä elämää, joka tundralle jääneitä on kohdannut. Vaikka Nerkagin teosten naispäähenkilöiden paluu tundralle on parhaimmillaankin epävarmaa, palasi Nerkagi itse isänsä sairastumisen myötä vuonna 1979 kotiseudulleen opiskeltuaan ja työskenneltyään tätä ennen Tjumenissa. Ennen paluutaan tundralle Nerkagi julkaisi esikoisteoksensa lisäksi pienoisromaanin Ilir (1979), mutta kirjailijan seuraavat teokset Valkea jäkälä (1996) ja Puhumaton (Moltšaštšì, 1996) valmistuivat vasta 1990-luvulla. Neljän pienoisromaanin lisäksi Nerkagi on julkaissut 2010-luvulla nenetsien kansanperinnettä, kuten sananlaskuja ja kertomuksia. Yhtäkään teoksista ei ole suomennettu. Nerkagin tuotannon pienuudesta huolimatta hän on yksi nenetsikirjallisuuden tärkeimpiä nimiä, mihin vaikuttaa varmasti myös Nerkagin vahva yhteiskunnallinen asema omalla kotiseudullaan. Uralin Federaatioyliopisto on myös ehdottanut Nerkagia Nobelin kirjallisuuden palkinnon saajaksi jo kolmesti, viimeksi vuoden 2020 keväällä (Urfu 2020).

Hypoteesina esitän, että Venäjän 2000-luvulla alkanut profiloituminen arktisena suurvaltana (Laruelle 2015, Hønneland 2016) ajankohtaisti kiinnostuksen alueeseen ja muun muassa Nerkagin pienoisromaaneihin, mikä johti niiden filmatisoimiseen vuonna 2014, lähes 20 vuotta jälkimmäisen teoksen ilmestymisen jälkeen. Filmatisointiajatukseen on saattanut vaikuttaa myös Nerkagin nimen esitteleminen Nobel-palkintokomitealle ensimmäistä kertaa vuonna 2015. Valkea jäkälä -nimeä kantava elokuva eroaa kuitenkin lähtökohdiltaan sen taustalla olevista kaunokirjallisista teoksista. Elokuvassa Nerkagin teokset on sijoitettu tapahtuvaksi 2010-luvulla sen sijaan, että elokuva sijoittuisi kirjojen tapaan 1970- ja 1990-luvuille. Myös elokuvan tarjoama näkökulma on huomattavasti Nerkagin teoksia suppeampi. Nerkagin teoksissa kerronta fokalisoidaan useita eri sukupolvia ja Nogo-suvun Anikossa jopa eri lajeja edustavien henkilöhahmojen kautta. Elokuva puolestaan keskittyy nuorempaa nenetsisukupolvea edustavien henkilöhahmojen näkökulmaan. Nenetsikulttuurin erityispiirteitä katsojalle avaavana taustaselostajana toimii Aljoška-niminen nenetsinuorukainen ja elokuvan kohtauksissa seurataan erityisesti häntä ja hänen ikätovereitaan. Olennaisin ero kirjojen ja elokuvasovituksen välillä liittyy kuitenkin tekijyyteen. Siinä missä Nerkagin teoksissa nenetseihin kuuluva kirjailija kuvaa oman kansansa elämää tundralla ja antaa heille äänen, on teosten elokuvasovitus monikansallinen produktio, jonka näkökulma nenetseihin on ulkopuolisen. Elokuvan ohjaaja Vladimir Tumajev on syntynyt Ukrainassa, käsikirjoittajat Valeri Bakirov 
ja Savva Minajev ovat venäläisiä, miespääosan esittäjä Jevgeni Sangadžiev on kansallisuudeltaan kalmukki ja naispääosien esittäjät Galina Tihonova ja Irina Mihailova puolestaan jakuutteja. Monikansallisesta tuotantoryhmästä huolimatta roolihahmot puhuvat elokuvassa keskenään nenetsin kieltä, ja keskusteluja seuraa vuorosanat venäjäksi tulkitseva ääniraita.

Vertailtaessa Nerkagin pienoisromaanien ja Tumajevin ohjaaman elokuvan representaatioita Venäjän arktisesta tundrasta on tärkeää muistaa, että niin romaanit kuin elokuvakin ovat omia itsenäisiä teoksiaan. Kuten Linda Hutcheon (2013, 8-9) esittää, teoksen muuntaminen toiseen muotoon eli adaptaatio on paitsi valmis tuotos, myös prosessi, jossa adaptoitava teksti tulkitaan ja luodaan uudelleen. Hutcheonia (ibid., 7, 20) mukaillen en ajattele, että elokuvasovituksen tulisi pyrkiä toisintamaan sen taustalla olevia teoksia, vaan ymmärrän ohjaajan luovan Nerkagin pienoisromaanien pohjalta oman taiteellisen esityksensä. Arvottamisen sijaan olen kiinnostuneempi niistä erilaisista tavoista, joiden avulla teokset luovat omaa kuvaansa arktisesta tundrasta tilana. Tämä pätee myös pienoisromaanien ja niiden elokuva-adaptaation tekijöiden erilaisiin kulttuurisiin taustoihin. Vaikka kaikkien teosten tapahtumapaikka on sama, elokuva kotouttaa tundran kuvauksen venäläistä katsojaa puhuttelevaan muotoon hyödyntämällä venäläisten tundralle antamia merkityksiä (vrt. Hutcheon 2013, 149-150). Elokuvan tapa hyödyntää tundran ulkopuolelta käsin luotuja kuvia ja merkityksiä alueen kuvaamisessa johtaa kuitenkin siihen, että alkuperäiskansan itsensä sijaan elokuvassa kuultava ääni kuuluu ulkopuoliselle. Tässä suhteessa Nerkagin teosten adaptaatioprosessi kytkeytyykin seuraavaksi käsiteltävän jälkikolonialistisen teorian piirissä esitettyihin huomioihin maantieteellisten alueiden tarkastelusta ulkopuolelta käsin.

\section{Tilallisuus ja jälkikolonialismi}

Niin sanotun tilallisen käänteen (Tally 2013, 11-15; Warf \& Arias 2009) myötä on alettu kiinnittää huomiota siihen, kuinka ihmisten väliset sosiaaliset suhteet muotoutuvat tilallisesti muovaten vastavuoroisesti ympäröivää tilallista todellisuutta (esim. de Certeau 1984, Lefebvre 1991, Soja 1996). Tiloilla ja tilallisuudella on oma, elimellinen roolinsa myös kirjallisuudessa, jossa tila tuotetaan karttojen sijaan kerronnan avulla (Tally 2013, 5, 45-46). Myös Nerkagin teosten tuottama kuva arktisesta tundrasta välittyy lukijalle kerronnallisesti juonessa, maisemakuvauksina, henkilöhahmojen ajatuksina ja heidän suhteessaan ympäröivään tilaan. Vastaavasti elokuvan voi nähdä kartankaltaisena tilan kuvaajana, mutta tekstuaalisten keinojen sijaan elokuvissa tila tuotetaan visuaalisin elementein (Bruno 2002; Castro 2009). Fyysisten paikkojen ja niiden kulttuuristen representaatioiden välinen suhde voidaan nähdä vuorovaikutteisena: siinä missä tekstit kuvaavat referentiaalisia paikkoja ja ympäristöjä, kyseiset paikat puolestaan muotoutuvat ja tulevat nähdyksi niistä tehtyjen kulttuuristen esitysten kautta (Tally 2013, 80-81).

Paikkojen ja tilallisuuden tarkastelu on merkittävässä asemassa myös jälkikolonialistisessa tutkimuksessa, jossa on pyritty purkamaan valtiorajat ylittäviä imperialistisia ja kolonialistisia valtasuhteita, ideologioita ja käytänteitä varsinaisen siirtomaa-ajan loputtuakin. ${ }^{2}$ Myös jälkikolonialistisen teorian avainteoksena pidetty Edward Saidin Orientalismi (1978) käsittelee erityisesti tilaa ja sen diskursiivista muodostumista. Orientalismissa Said osoittaa, kuinka käsitykset idästä eli "orientista" muodostavat yhteiskunnan eri tasoilla ylläpidetyn diskurssin. Tämä diskursiivinen valta on ollut historiallisesti merkittävä kolonialistisen vallankäytön ulottuvuus. Samalla eurooppalainen tai läntinen identiteetti on rakentunut suhteessa toiseksi miellettyyn orienttiin. Orientin representaatioihin Said viittaa termillä kuvitteellinen maantie- 
de. Vaikka representaatioissa kuvataan olemassa olevaa maantieteellistä aluetta, perustuvat ne niiden laatijoiden mielikuviin ja käsityksiin tästä alueesta ja tuottavat kuvitelmaa sekä representaation kohteena olevasta toisesta että itsestä. (Said 2011, 59-63.) Orientalismin käsitettä on sovellettu Venäjän tutkimuksessa tarkastelemalla Venäjää imperialistista politiikkaa harjoittavana ja omia orientalistisia diskurssejaan tuottavana suurvaltana (Layton 1994, Jersild 2002, Schimmelpenninck van der Oye 2010). Toisaalta Saidin teorian soveltamista Venäjän kontekstissa on myös kritisoitu (Knight 2000) ja tutkimuksissa on tuotu esiin Venäjän oma asema orientalistisena toisena suhteessa muuhun Eurooppaan (Layton 1994, 79-81).

Juha Ridanpää $(2017,259)$ soveltaa kuvitteellisen maantieteen käsitettä pohjoiseen, jonka representaatioiden hän näkee syntyneen pohjoiseen ulkopuolelta käsin liitetyistä kuvista ja kuvitelmista. Ridanpään lisäksi myös Anka Ryall, Johan Schimanski ja Henning Waerp (2010) ovat luoneet käsitteen "arktisismi" (arcticism) kuvaamaan arktisen alueen diskurssia, joka mahdollistaa imperialistisen valloittajan, tutkimusmatkailijan ja muiden arktiseen alueeseen sidoksissa olevien subjektipositioiden muotoutumisen. Myös Neuvostoliiton arktinen diskurssi voidaan nähdä tällaisena orientalistisena tai arktisistisena kuvitteellisena maantieteenä, "arktisena myyttinä" jossa sosialistisen realismin muoto ja teknologisen kehityksen ihannointi yhdistettiin arktiseen alueeseen liitettyyn mystiikkaan (McCannon 1998). Myös Venäjän 2000-luvulla voimistuneen arktisen alueen diskurssin voi nähdä tuottavan oman kuvitteellisen maantieteensä.

Sen lisäksi, että tiloja voidaan kuvitella niitä asuttavien yhteisöjen ulkopuolelta käsin, myös yhteisöjen omat käsitykset tiloista ja paikoista rakentuvat diskursiivisesti esimerkiksi kerronnan ja toiminnan kautta (esim. Anderson 1991; Ridanpää 2017, 261-262; Bacchilega 2007, 8). Alkuperäiskansojen keskuudessa asuinympäristö kytkeytyy myös maailmankatsomukseen sekä tietoon kyseisestä tilasta (Basso 1996, Thornton 2007) ja esimerkiksi Nerkagin pienoisromaanien luoma tundran kuvitteellinen maantiede kytkeytyy nenetsien käsitykseen ei-inhimillisestä luonnosta ja ihmisen ja ei-inhimillisen välisestä suhteesta. Siinä missä Saidin teoriassa kuvitteelliset maantieteet tukevat kolonialistisia diskursseja, alkuperäiskansojen ja muiden geopoliittisiin marginaaleihin jääneiden ryhmien kuvitteellisissa maantieteissä voi nähdä dekolonialistista potentiaalia. Esimerkiksi Sarah Radcliffen (1996) mukaan näiden avulla kyseiset ryhmät voivat neuvotella itse omasta paikastaan sekä maailmankartalla että kansallisvaltioiden sisällä.

\section{Imperiumin laidalla}

Arktista tundraa eniten määrittävä piirre sekä Nerkagin teoksissa että niiden filmatisoinnissa on alueen perifeerinen sijainti. Periferian ja asutuskeskusten välisestä jännitteestä muodostuu teosten keskeinen problematiikka, joka määrittää henkilöhahmojen välisiä suhteita sekä teoksissa esiintyviä laajempia yhteiskunnallisia ja sosiaalisia kysymyksiä. Perifeerisyyden tematiikka kytkeytyy olennaisesti Neuvostoliiton ja Venäjän maantieteelliseen laajuuteen. Kysymys Venäjän suunnattomista mittasuhteista sekä rajattomasta pinta-alasta ja sen haltuunotosta on määrittänyt ensin Venäjän kansallista identiteettiä ja toiminut rakennusaineena myös Neuvostoliiton kansalliselle projektille. (Widdis 2004, Turoma 2013). Kansallista identiteettiä rakennettaessa Venäjän ja Neuvostoliiton maantieteellistä laajuutta on tarkasteltu ennen kaikkea maan valtakeskuksista käsin. Stalinin ajan kuvastossa viitataan selvästi neuvostoimperiumin maantieteellisen valloituksen keskusjohtoisuuteen (Widdis 2004, 48) kun taas 1960-luvulla maan laajuus ja monimuotoisuus haluttiin tuoda nimenomaan venäjänkielisen 
kaupunkilaisyleisön nähtäväksi (Turoma 2013, 255-256). Nerkagin romaaneissa ja niiden elokuvaversiossa maan pinta-alallista laajuutta tarkastellaan puolestaan periferiasta käsin, joskin teosten välillä voi nähdä eroavaisuuksia siinä, kuinka perifeerisyyttä ja periferian ja valtakeskusten välistä suhdetta kuvataan.

Siinä missä valtakeskusten sisällä käydyssä keskustelussa ja niille suunnatuissa representaatioissa Venäjän maantieteellinen laajuus ja monimuotoisuus on pyritty tekemään kansalaisille näkyväksi, Nerkagin teoksissa perifeerisen tundran ja asutuskeskusten välinen suunnaton etäisyys tuodaan esiin pikemminkin poissaolon kautta. Yksi merkittävimmistä tavoista, joiden kautta tämä poissaolo konkretisoituu, on nenetsinuorten puuttuminen näiden muutettua sisäoppilaitoksiin ja asutuskeskuksiin. Nuorten ja tundralle jääneiden sukulaisten välimatkaa korostaa epäselvyys nuorten tarkasta olinpaikasta. Nogo-suvun Anikon alussa "kukaan leirissä, ei edes Seberui itse"3 (Nerkagi 1996b, 312) tiedä tämän tyttären tarkkaa olinpaikkaa tai ikää ja Valkeassa jäkälässä vanhan Petkon tyttäret ovat puolestaan "siellä jossain, tuntemattomassa kylässä" (Nerkagi 1996a, 12). Vanhemman sukupolven näkökulmasta nenetsinuorten hylkäämiksi eivät tule vain näiden vanhemmat, vaan koko tundra ja siellä asuva alkuperäiskansayhteisö.

Pienoisromaaneissa on kuitenkin nähtävissä ero siinä, kuinka teoksissa nuorten lähtöön suhtaudutaan. 1970-luvulla julkaistussa Nogo-suvun Anikossa on vielä ääniä, jotka ilmaisevat uskoa nuorten palaamiseen ja koulutuksen hyötyyn alkuperäiskansalle: "Nyt hän uskoi vankasti: lapsille tuli opettaa lukutaitoa, jotta järkevällä päällä varustetut voisivat keksiä hyvän ja lämpimän kodan, jossa talvella voisi riisua maalitsan ${ }^{4}$ muulloinkin kuin kamiinan ollessa lämmin (Nerkagi 1996b, 311)." Omien elämänvalintojensa kanssa kamppailevan Anikon rinnalle nostetaan myös nuoria, jotka ovat päättäneet jäädä tundralle: Anikon entinen luokkatoveri on palannut kotiseudulleen läk̈kintätehtäviin taistelemaan seudulla rehottavaa alkoholismia vastaan ja tundralla asuva nuori venäläinen geologi taltioi nenetsien kansanperinnettä. 1990-luvulla julkaistu Valkea jäkälä on edeltäjäänsä synkempi ja teos kritisoi nenetsivanhusten äänellä nuorten saamaa koulutusta tundran olosuhteisiin nähden hyödyttömänä: "Kouluissa opetettiin lapsille kaikenlaista: lukemaan paperia, katsomaan sen sieluun ja leikkimään kummallisia leikkejä, mutta elämän taitoja, itsensä ja perheen ruokkimista ei opetettu" (Nerkagi1996a, 39).

Kaupunkeihin kadonneen nuorison lisäksi myös Neuvostoliiton arktisen alueen modernisaatioprojekti puuttuu Nerkagin teosten maalaamasta tundramaisemasta, ja elämä tundralla määäytyy vuoden kierron ja porojen laidunnusrytmin mukaisesti. Siinä missä Widdis (2004, 47) osoittaa, kuinka Stalinin ajan kuvastossa korostetaan neuvostovallan kykyä kesyttää ja muuntaa maantieteellisiä lakeuksia yhdeksi, vaikkakin monimuotoiseksi, tilaksi, Nerkagin kuvaama 1990-luvun tundra näyttäytyy muusta maasta erillisenä ja keskusvallan hylkäämänä kolkkana: "Taajamaa vain kutsuttiin sillä nimellä, todellisuudessa se oli pelkkä pikkuruinen kauppapaikka. [...] Tämä orvoksi jäänyt, hylätty ja maailman voimakkaiden kauan sitten unohtama kauppapaikka selviytyi vain omasta halustaan elää" (Nerkagi 1996a, 50-51). Monien muiden alkuperäiskansakirjailijoiden tavoin (vrt. Boliachevets \& Sablin 2016) myös Nerkagin teoksista välittyvä kuva bolševikkien ja kolhoosien vaikutuksesta elämään tundralla on positiivinen:

Vaikka aiemmin, vallankumousta seuranneina vuosina ja niiden jälkeen kolhoosien aikaan, elämä täällä kihisi ja kuhisi muurahaiskeon lailla. [...] Niin 'Punainen pohjoi- 
nen' eli omalla työllään kuin yksi iso nenetsiperhe, ja 'neuvosto' oli yhtä kuin kolhoosi (Nerkagi 1996a, 51).

Kolhoosien lakkauttaminen puolestaan on kuolinisku yhteisölliselle elämälle, jonka muisto pyyhkiytyy lopulta pois myös maisemakuvasta: "Kaikki hajosi niin kuin mitään ei olisi koskaan ollutkaan. Asteittain tyhjä turkistarha, talli ja navetta, kaikki lahosivat ja sortuivat maan tasalle" (emt., 52). Valkean jäkälän pohjoisen kuvauksessa heijastuu 1990-luvun yhteiskunnallinen murros, kun Neuvostoliiton aikana pystytetty infrastruktuuri romahti jättäen siihen neuvostoaikoina sidotun alkuperäisväestön lähes tyhjän päälle alueelle muuttaneiden venäläisten palattua takaisin maan keskiosiin (Vitebsky 2005, 380-382).

Valkeassa jäkälässä Nerkagi tuo myös esiin sen, kuinka alueen resurssit kulkeutuvat kolonialistista logiikkaa noudattaen pois tundralta. Konkreettisimmin tämä dynamiikka tulee esiin vanhan Hasavan kertomuksessa, jossa ympäröivä yhteiskunta haluaa osansa poronomistajan poroista vallitsevasta yhteiskuntajärjestyksestä riippumatta. Aluksi Hasavan porojen perässä on neuvostovalta, joka vaatii poroja "salaperäisen 'suunnitelman" täyttämiseksi (Nerkagi 1996a, 77). Myöhemmin tämän kaupunkiin muuttanut jälkikasvu tulee vaatimaan isältään poroja ennakkoperinnöksi nähden eläimissä uuden kapitalistisen yhteiskuntajärjestyksen mukaisesti rahaa. Vaikka sekä Hasava että muut nenetsivanhukset luopuvat vaadittaessa niin lapsistaan kuin poroistaankin, jättää ympäröivä yhteiskunta tundran ja siellä asuvien alkuperäiskansayhteisöjen tarpeet huomiotta. Tätä logiikkaa vasten Valkeassa jäkälässä esiintyvä kiitollisuuden ja vastavuoroisuuden tematiikka erottuukin selkeästi ihanteena kiittämättömyyden ja suoranaisen riiston leimaamassa yhteiskunnallisessa tilassa.

\section{Tundra osana Venäjää}

Myös Tumajevin elokuva luo tundrasta kuvan perifeerisenä ja harvaan asuttuna seutuna. Tätä vaikutelmaa korostaa tundran valtava laajuus, jota esitellään heti elokuvan alussa helikopterista avautuvasta lintuperspektiivistä käsin. Perspektiivi paljastaa päättymättömältä vaikuttavan lumisen lakeuden, jossa ihmisen kädenjälki loistaa poissaolollaan. Näkymä autiolta vaikuttavasta lumisesta tundrasta on yhteydessä läntisessä ja venäläisessä kulttuurissa jo 1800-luvun lopulla vallinneisiin mielikuviin, joissa pohjoinen ja arktinen alue näyttäytyvät koskemattomana ja saavuttamattomana (Bloom 1993, 2-3, Eglinger 2010, McCorristine 2018, 4). Nerkagin pienoisromaanien kerronnasta välittyvä ympäristö määrittyy puolestaan ennen kaikkea alkuperäiskansan toimintaympäristönä, joka kuvataan asumisen, liikkumisen ja muun toiminnan kautta. Aluetta kuvataan maan pinnan tasolta käsin ja useimmiten henkilöhahmojen silmin. Ylhäältä avautuvan lakeuden sijaan Nerkagin henkilöhahmot kiinnittävät huomiota tundran pintaan, jota pitkin he porolaumoineen kulkevat ja josta käsin myös korkeat luonnonmuodostelmat nähdään. Karusta ilmastosta huolimatta maisema ei näyttäydy tyhjänä ja yksitoikkoisena, vaan vivahteikkaana ja täynnä yksityiskohtia. Beatrice Reedin (2018) näkemykseen pohjaten tundran paikoitellen jopa antropomorfiset kuvaukset korostavat ihmisen ja ympäröivän luonnon yhteenkuuluvuutta sekä vastustavat myös kolonialistisille diskursseille ominaista tiukkaa rajanvetoa inhimillisen ja ei-inhimillisen välillä:

Suuret vuoret eivät pidä ihmishälinästä, porojen tömistelystä ja koirien haukunnasta. [...] Huonolla säällä riippuvat, surkeat, taivaaseen katoavat vuorenhuiput muistuttavat päitä, jotka katsovat alas järven syvyyksiin. Ja pitkin niiden ikivanhoja syvistä aatoksista 
Siinä missä Nerkagin teoksissa maan syrjälaidalla sijaitseva tundra näyttäytyy muusta maasta erillisenä ja valtakeskusten hylkäämänä syrjäseutuna, välittyy teosten filmatisoinnista kuitenkin kuva tundrasta perifeerisenä mutta silti muuhun maahan yhteydessä olevana seutuna. Yksi suurimmista tähän vaikuttavista tekijöistä on elokuvan sijoittuminen 2010-luvulle, ja sen myötä tundrallekin levinnyt nykyteknologia. Nogo-suvun Anikossa Seberui ottaa yhteyttä tyttäreensä kirjeitse. Anikon tavoittamisen epävarmuutta ja vaivalloisuutta korostaa se, että kirje hukkuu Anikon kotona vaatteiden joukkoon kuukaudeksi. Myös matka kotiseudulle on hankala, lentokentällä Aniko saa tietää, että kotiseudulle lentävät vain rahti- ja postikoneet, joiden kyytiin pääseminen on yksityishenkilöille epävarmaa. Elokuvasovituksessa vastaavia ongelmia ei ole: Anikoon otetaan yhteys kännykällä ja matkaliput tundralle ovat ostettavissa hinnasta sovittaessa. Elokuvassa tundran perifeerisyys ei tarkoitakaan enää eroa muuhun maailmaan. Tundra näyttää kaukaiselta ja hankalasti tavoitettavalta, puhelinverkko joudutaan etsimään kipuamalla tähystystorniin, mutta yhteys ympäröivään maailmaan on kuitenkin olemassa.

Sen lisäksi, että yhteydenpito tundralta ulospäin on Nerkagin kirjoissa kuvattua vaivattomampaa, teknologia tuo myös ulkomaailman tundralle. Nenetsien perinteiseen kota-asumukseen tuodusta televisiosta näkyy uutislähetys, jossa kerrotaan Tšeljabinskiin pudonneesta meteoriitista. Venäjän lisäksi tundralle tuodaan myös ulkomaiden tapahtumia: kohtaus Savanen ja Aljoškan häistä alkaa kuvalla television päälle nostetusta tabletista, jolta häävieraat katselevat lähetystä Prinssi Williamin ja Catherine Middletonin häistä - venäjäksi dubattuna alkuperäisen englanninkielisen ääniraidan kuuluessa taustalta. Brittikuninkaallisten häät vertautuvat nuorten nenetsien hääjuhlaan, mutta samalla elokuva hyödyntää transnationaalia mediakuvastoa (vrt. Appadurai 1996, 35-36) viestiäkseen tilaisuuden luonteesta ulkopuoliselle katsojalle, jonka silmiin tapahtuma saattaisi vaikuttaa tavalliselta aterialta, mikäli sen yhteyteen ei tuotaisi ympäri maailman levinnyttä kuvastoa brittikuninkaallisten hääjuhlasta. Yhtäältä elokuvan tapa näyttää teknologian sulautumista alkuperäiskansan elämään purkaa binäristä ajattelutapaa, jossa alkuperäiskansojen perinne nähdään modernisaatiolle päinvastaisena ja nämä kaksi toisensa poissulkevina (ks. esim. Germond-Duret 2016). Toisaalta ilmiön voi nähdä myös keinona, jolla alkuperäiskansan asuttaman alueen osoitetaan kuuluvan sen perifeerisyydestä huolimatta Venäjään. Liikenne- ja teleoperaattoriyhteydet kytkevät alueen emomaahan, televisio välittää tietoa maan tapahtumista ja lähetysten kieli on koko maata yhdistävä venäjä.

Tundran ja muun maan välisen yhteyden esiin tuomisen lisäksi tundran alkuperäisväestön kuvataan tulleen osaksi venäläisen valtakulttuurin vaikutuspiiriä. Aljoškan kotitelttaa koristaa ikoni, jonka hänen äitinsä kääntää katsomaan seinää päin rukoillessaan esi-isiaän, ja erään nenetsivanhuksen vieraillessa venäläisen kauppiaan luona vanhus viittaa Venäjän jalkapallomaajoukkueeseen "meidän joukkueenamme" osoittaen kuuluvuutensa Venäjän maajoukkueen edustamaan yhteisöön. Kuten Mishuana Goeman (2013,35-36) kirjoittaa, elokuvassakin esitetyn kaltainen monikulttuurisuuden korostaminen voi kuitenkin toimia asuttajakolonialistista järjestystä ylläpitävänä keinona, jolla hämärretään rajaa alkuperäiskansan ja kolonialistisen vallan välillä. Korostamalla nenetsien kotiseudun ja muun maan välisiä yhteyksiä Tumajevin elokuva tuottaa alueesta valtakeskuksesta käsin luotua kuvitteellista maantiedettä, jossa linkki tundran ja muun maan välillä on vahva sekä konkreettisesti että 
symbolisesti erilaisten kulttuuristen merkkien kautta. Venäjän vaikutuspiirin korostaminen sen arktisilla alueilla näyttäytyy myös luontevana jatkumona Venäjän 2000-luvulla uudelleen aktivoituneelle tavalle määritellä omaa kansallista identiteettiä nimenomaan arktisena suurvaltana.

Nerkagin teoksista vastaava Venäjän ja venäläisen kulttuurin läsnäolo puuttuu. Näiden sijaan teoksista kuvastuu alkuperäiskansan oma historia, joka kietoutuu osaksi tundran maisemaa. Tällainen historian ja maiseman yhteen kietoutuminen nousee esiin esimerkiksi Nogo-suvun Anikon kohtauksessa, jossa Nogo-suvun hautausmaan kuvaus kytkeytyy kuvaukseen nenetsisuvun historiasta omalla kotiseudullaan:

Hautausmaa on muinainen. Sinne on haudattu ihmismuistia kaukaisemmilta ajoilta alkaen Nogo-suvun jäseniä. [...] Tässä lepäävät Seberuin isä, hänen äitinsä, isoisä, isoäiti ja lapset, jotka Nga-idoli ${ }^{5}$ on vienyt mukanaan. Nyt myös vaimo ja pieni tytär tulevat odottamaan täällä häntä, kauan sitten niin suuren ja hyvän suvun viimeistä miestä. (Nerkagi 1996b, 316.)

Fyysisen hautausmaan kuvailu yhdistyy Nogo-suvun elämäkertaan ja kuljettaa lukijan suvun varhaishistoriasta aina takaisin hautuumaalla sijaitseviin arkkuihin ja niissä lepääviin vainajiin. Hautausmaa edustaakin Cristina Bacchilegan $(2007,8)$ ajatusta "tarinallistetusta paikasta" (storied place), jossa alkuperäiskansan kotiseudun materiaalinen ympäristö ja fyysiset paikat muotoutuvat kansanperinteen ja muistojen kautta kytkökseksi alkuperäiskansan edustajien ja näiden esi-isien välillä. Tilan representaation kytkemisen alkuperäiskansan historiaan voi nähdä myös keinona muistuttaa näiden läsnäolosta alueella jo ennen alueen liittämistä Venäjän vaikutuspiiriin. Tumajevin elokuvasta puuttuvat vastaavanlaiset kytkökset tundran ja nenetsien historian välillä. Normalisoimalla venäläisen kulttuurin läsnäolo alueella ja sivuuttamalla alkuperäiskansan venäläistä hallintoa edeltävä historia elokuva välttää herättämästä kysymyksiä asuttajakolonialismista ja ylläpitää vallitsevaa järjestystä Goemanin (2013, 35-36) osoittamalla tavalla.

Siitä huolimatta, että Nerkagin teoksista tehty filmatisointi esittää alkuperäiskansan kotiseudun osana Venäjää, elokuvasta välittyy alkuperäiskansan edustajiin kohdistuva alentuva asenneilmapiiri. Tätä asenneilmastoa edustaa elokuvan tundralla toimiva venäläinen kauppias, joka tuo kaupankäyntitilanteissa esiin omaa hierarkkisesti korkeampaa asemaansa. Alkuperäiskansan sosiaalisesti heikompi asema venäläisen silmissä kytkeytyy näiden stereotyyppiseen alkoholin liikakäyttöön, jota elokuvassa tuodaan esiin huomattavasti Nerkagin pienoisromaaneja enemmän. Nogo-suvun Anikossa alkoholismi mainitaan alueen väestöä koskettavana ongelmana, mutta teoksen päähenkilöitä ei kuvata kertaakaan päihtyneenä. Elokuvassa puolestaan sekä leirin nenetsivanhukset että myöhemmin myös Aljoška kuvataan päissään ja ajoittain päihtymystiloihin liitetään myös koomisia elementtejä. Sama alentuvuus paikallisten alkoholinkäyttöä kohtaan näkyy myös kaupunkiin muuttaneiden lasten puheessa. Viitatessaan nenetsien alkoholinkäyttötottumuksiin, yksi kaupungista tundralle tulleista lapsista toteaa: "me emme ole sellaisia nenetsejä" (Belyj jagel 2014, 00:41:18). Persous alkoholille näyttäytyykin elokuvassa nimenomaan tundralla asuvan alkuperäisväestön ongelmana. Alkoholismi erottaa nämä alueen venäläisestä kauppiaasta, joka ei itse joisi myymäänsä huonolaatuista mutta nenetseille kelpaavaa vodkaa (emt., 00:41:12), sekä tundralle jääneiden nenetsien kaupunkiin muuttaneista sukulaisista. Vaikka venäläisen kauppiaan halveksunta alkoholinhimoisia nenetsejä kohtaan herättää katsojassa kriittisiä ajatuksia, näyttäytyy vodkapulloja kitsaasti kaup- 
paava venäläinen myös eräänlaisena nenetsien suojelijana rajoittaessaan tällä tavoin näiden alkoholin käyttöä. Kohtuuttomuudessaan alkoholinkäytön suhteen alueen alkuperäisväestö näyttää ikään kuin tarvitsevan ulkopuolisen valvontaa, mikä puolestaan tekee tundran tiiviistä suhteesta muuhun maahan jopa alkuperäiskansaväestön itsensä kannalta tarpeellista. Tällainen kuvaus alkuperäiskansan edustajista edustaa kolonialistisen diskurssin stereotyyppiä, jossa kolonisoidun kansan edustajat näyttäytyvät lapsenkaltaisina verrattuna henkisen kypsyyden saavuttaneisiin valkoisiin kolonisoijiin (Loomba 2015, 142-143).

\section{Ruumiillistetut tilallisuudet}

Sekä Nerkagin teoksissa että Tumajevin elokuvassa tila ja henkilöhahmot yhdistyvät tavassa, jolla henkilöhahmojen fyysiset ruumiit heijastavat niille ominaisia tilallisuuksia. Nenetsinuorten poissaolon myötä Nerkagin teosten maalaama kuva tundrasta henkilöityy sinne jääneissä vanhuksissa. Valkean jäkälän vanhukset vertautuvat yhteiskunnan hylkäämään tundraan ja erityisesti alueella rappeutuvaan entiseen kolhoosiin. Siinä missä perifeerisen kauppapaikan rakennukset lahoavat ajan saatossa, kuihtuvat vanhenevine kehoineen myös tundran vanhukset, joita nuoret eivät palaa hoitamaan. Kirjoista tehdyssä elokuvasovituksessa puolestaan tundra- ja kaupunkialueiden välinen jännite tiivistyy kahteen näitä alueita edustavaan naiseen, joiden väliltä Aljoška joutuu valitsemaan. Savanen ja Anikon asuinseudut, tundra ja kaupunki, piirtyvät naisten fyysisiin hahmoihin, mikä redusoi naiset yksilöllisten persoonien sijaan kotipaikkakuntiensa symboleiksi.

Selkeimmin naisten symboloimat tundra- ja kaupunkitilat tulevat esiin näiden vaatteiden ja muiden asusteiden kautta. Savane pukeutuu nenetsien perinteisiin poronnahasta tehtyihin vaatteisiin ja koristautuu alkuperäiskansalle tyypillisin hiuskoruin ja pannoin. Katsojan ensimmäinen välähdys Anikosta on puolestaan leikkaus, jossa tarkennetaan tämän mustiin piikkikorkonilkkureihin ja farkkujen peittämiin nilkkoihin, josta kuva nousee pitkin naisen vartaloa tavoittaen tämän käsilaukun, venäläisen karvareunaisella hupulla varustetun toppatakin ja ehostetut kasvot. Jopa Anikon perässään vetämä matkalaukku kielii hänen kaupunkilaisstatuksestaan: laukussa komeilee maailman tunnetuin metropoli, kuva Manhattanista iltaruskossa. Sama vastakkainasettelu näkyy myös naisten tavassa toimia nenetsileirissä. Aniko kantaa mukanaan älypuhelinta ja etsii verkon kautta kontaktia kaupunkiin jääneisiin ystäviinsä sekä sulkeutuu nappikuulokkeiden avulla puhelimesta kantautuvaan pop-musiikkiin. Savane puolestaan ohjaa suvereenisti pororekeä ja suorittaa teltassa nenetsinaiselle kuuluvat kotiaskareet. Kaiken kaikkiaan Savanen ja Anikon tavat symboloida tundra- ja kaupunkitilaa ovat varsin yksioikoiset ja stereotyyppiset, mikä puolestaan lisää vastakkainasettelua naisten edustamien alueiden välillä. Naishahmojen käyttäminen tundran ja kaupungin symboleina johtaa siihen, että naisten välillä valitsemisen sijaan Aljoška käy sisäistä taistelua kahden asuinpaikan välillä. Alkuperäiskansanuorten tekemä päätös asuinpaikasta rinnastuu elokuvassa näin ollen heteroseksuaaliseen haluun. Kaupunki näyttää nuorten silmissä yhtä houkuttelevalta ja eksoottiselta kuin Aniko Aljoškan silmissä, kun taas kotitundra on Savanen lailla perinteen värittämä ja vanhempien sekä yhteisön odotuksia edustava - onhan Savanen Aljoškan morsiameksi valinnut tämän äiti eikä nuorukainen itse.

Luentaa elokuvan naispäähenkilöistä tundra- ja kaupunkitilojen symboleina tukee myös elokuvan loppu, jossa Aljoška toteaa tehneensä päätöksen nimenomaan asuinpaikkansa ja elämäntapansa eikä vain kumppaninsa suhteen ja kertoo katsojalle: "Minä tein oman valintani ja päätin jäädä asumaan tähän maahan, ja tämän taivaan alla tulevat elämään myös 
lapseni” (Belyj jagel 2014, 01:33:37). On kuitenkin perusteltua kysyä, missä määrin päätös tundralle jäämisestä on lopulta Aljoškan oma ja missä määrin olosuhteiden sanelema. Aljoškan rakkaudentunnustuksesta huolimatta kaupunkiin oman elämänsä rakentanut Aniko nousee helikopteriin ja lentää pois tundralta jättäen nenetsimiehen huutamaan naisen, tai tämän edustaman elämänvalinnan, perään. Myös Aljoškan viimeiset sanat elokuvan lopussa asettavat Aljoškan tekemän valinnan vapauden kyseenalaiseen valoon: "Ja kenties jonakin päivänä onnistun unohtamaan myös Anikon" (emt., 01:33:46.) Siitä huolimatta, että elokuva pyrkii rakentamaan narratiivin, jossa alkuperäiskansaa edustava nuori päättää jädä ja rakentaa tulevaisuutensa perifeeriselle kotiseudulleen, näyttää tundralle jääminen lopulta pakon sanelemalta kohtaloon tyytymiseltä. Tässä suhteessa elokuvan voi nähdä heijastavan ulkopuolisten, erityisesti valtakeskuksissa asuvien käsityksiä perifeerisestä alueesta tilana, jossa asuminen tai jonne jääminen pitää sisällään kaipuun kaupunkiin.

Kaupunkielämän houkutus alkuperäiskansanuorison parissa nousee esiin myös Nerkagin pienoisromaaneissa, todetaanhan Valkean jäkälän alussakin että "[t]oisenlainen elämä houkutteli puoleensa kuin makea salaisuus" (Nerkagi 1996a, 66). Nerkagin Nogo-suvun Anikossa käytetty kerronta paljastaa sen sisäisen kamppailun, jota Aniko mielessään käy omien toiveidensa ja ulkopuolelta tulevien odotusten välisessä ristitulessa. Elokuvassa Anikon ristiriitaiset ajatukset eivät tule esiin ja kaupunkiin muuttaneen mutta tundralle palaavan henkilöhahmon näkökulma jää esittämättä. Nenetsinuorten tekemän elämänvalinnan esittäminen kolmiodraaman muodossa hioo myös pois tämän valinnan yhteiskunnallisen ja sosiaalisen merkityksen, joka nousee Nerkagin teoksissa merkittävään rooliin. Myös Nerkagilla tämä valinta näyttäytyy viimekädessä yksilön omana, mutta pienoisromaaneissa käytetty moniääninen kerronta tuo esiin kysymyksen moniulotteisuuden. Pienoisromaaneissa fokalisaatio tapahtuu vuoroin tundralla asuvien vanhusten ja vuoroin näiden jälkipolven edustajien näkökulmasta käsin. Erityisesti vanhusten kokemuksessa painottuu teosten aihepiirin sosiaalinen merkittävyys. Nenetsivanhukset ovat läsnä myös elokuvassa, mutta näiden kokemuksen sijaan vanhukset kuvataan stereotyyppisinä alkoholisoituneina alkuperäisasukkaina, jotka ovat kiinnostuneempia uuden vodkapullon hankkimisesta kuin lastensa saamisesta tundralle. Keskittyessään nuorten väliseen kolmiodraamaan elokuva sivuuttaa myös ympäröivän yhteiskunnan roolin tundran tilanteen muodostumisessa. Siinä missä Nerkagin teoksessa osoitetaan, kuinka tundran tilanteen takana on alueen laiminlyöntiä keskusvallan toimesta ja epäonnistunutta koulutuspolitiikkaa, eivät nämä näkökulmat nouse elokuvassa kertaakaan esiin.

\section{Monilajinen tundra}

Tilan ja materiaalisten ruumiiden välinen yhteys ei rajoitu ainoastaan ihmisiin, vaan näiden ohella arktiseen tilaan kuuluvat myös lukuisat ei-inhimilliset ruumiillisuudet. Tilan ja ihmisten sekä ei-inhimillisten toimijoiden välinen vuorovaikutus näyttäytyy kuitenkin erilaisena Nerkagin teoksissa ja Tumajevin elokuvassa. Pienoisromaanit maalaavat tundrasta kuvan monilajisena tilana, jossa ihmiset, eläimet ja ympäristö ovat erottamattomasti toisiinsa sidotut $^{6}$. Tässä suhteessa Nerkagin pienoisromaanien tuottaman tilan voi nähdä myötäilevän alkuperäiskansojen parissa tavattua käsitystä, jossa myös ei-inhimilliset entiteetit nähdään ihmisten kaltaisina henkilöllisyyksinä (esim. Hallowell 1960, Willerslev 2007). Nogo-suvun Anikossa tilan kuvauksen monilajisuus tuodaan esiin konkreettisesti teoksen kerronnassa, sillä ihmishahmojen lisäksi kertomusta fokalisoidaan myös ei-inhimillisten hahmojen silmin. Ihmisten elinpiirin rinnalla myös ei-inhimillinen näkökulma esitetään relevanttina kokemuk- 
sena ympäröivästä tilasta ja se pyritään välittämään lukijalle sellaisen kerronnan kautta, jossa korostuvat näköaistin sijaan muut aistihavainnot:

Juuri äsken on satanut. Tuoksuu sammaleelta, kosteilta kiviltä ja ennen kaikkea lehdistöltä, jota pitkin valuvat raskaat, läpinäkyvät pisarat. [...] Jotain värähti ilmassa. Oikopäätä singahtava jänis, joka piiloutui välittömästi kumpareen taakse. Sieltä kantautui välittömästi jonkun pikkulinnun mielipuolinen piipitys ja jälleen tuli hiljaista - mutta ei pitkäksi aikaa. (Nerkagi 199b, 390.)

Ei-inhimillisen kokemusmaailman lisäksi tundralle ominaista lajien välistä vuorovaikutusta kuvataan tiiviiden monilajisten suhteiden kautta. Anikon edesmennyt äiti pelastaa orvoksi jääneen porovasan imettämällä tätä omalla rintamaidollaan. Anikon isä Seberui ja tämän Buro-koira ovat puolestaan tiivis parivaljakko, jonka lähes telepatiankaltainen yhteys kerronnallistetaan esittämällä sama ajatus tai huomio puoliksi ihmisen ja puoliksi koiran tekemänä: "Buro kohottautui ja jännitti korviaan kuullessaan ulkoa kantautuvia ääniä. 'Passa ja Aljoška saapuivat', ajatteli Seberui." (emt., 310). Myös elokuvassa kuvataan sivumennen ihmisen ja koiran välistä kumppanuutta, mutta näiden välinen suhde saa hyvin erilaisen sävyn. Aljoškan torjumaksi tullut Savane kohdistaa hellyytensä pieneen koiranpentuun, jota hän syöttää ja lämmittää maalitsansa sisällä. Kahden itsenäisen olennon välisen kumppanuuden sijaan Savanen hoivaama koiranpentu on pikemminkin lapsenkorvike, joka symboloi Savanen ja Aljoškan täyttymätöntä avioliittoa.

Elokuvassa ei-inhimilliset eläimet, etenkin porot ja erityisesti lintuperspektiivistä kuvatut porolaumat näytetään osana tundramaisemaa. Porot ovat venäläisessä ja läntisessä kuvastossa tyypillinen pohjoista aluetta merkitsevä eläin, jonka sisällyttäminen elokuvan tilan kuvauksiin rinnastuu muihin elokuvassa esitettyihin kliseisiin maisemakuviin, luonnottoman kirkkaaseen tähtitaivaaseen ja revontuliin. Nämä arktista luontoa eksotisoivat kliseet on selkeästi tarkoitettu ruokkimaan ulkopuolisen katsojan arktisen kuvitteellista maantiedettä. Toisaalta porojen ja muun ei-inhimillisen luonnon voimakas liittäminen osaksi alkuperäiskansan kotiseudun visuaalista representaatiota kytkee elokuvan kolonialistisille diskursseille tyypilliseen luonto/kulttuuri -binaariin, jossa länsimaalainen tai valkoinen edustaa kulttuuria, kun taas toiseutettu kolonisoitu rinnastuu luontoon (Loomba 2015, 88). Nerkagin pienoisromaanissa vastaava kuvasto puuttuu täysin. Katsojille kuitenkin avataan porojen merkitystä nenetseille Aljoškan taustaselostuksen avulla, ja aihe nousee elokuvan tarinassa esiin myös Nerkagin pienoisromaanista tutussa kohtauksessa, jossa Hasava joutuu teurastamaan porojaan lastensa vaatimuksesta. Lähikuvat tyhjyyteen katsovan nenetsivanhuksen vereen tahriutuneista käsistä ja kasvoista luovat irvokkaan kontrastin suhteessa seuraavaan otokseen, jossa nenetsimiehen kaupunkilaistunut poika heittelee tyytyväisesti hyräillen nyljettyjä ja jäätyneitä poronruhoja peräkärryyn. Vaikka porojen aseman merkitys nenetsikulttuurille tuodaankin elokuvassa esiin, elokuvan tarkastelukulma keskittyy ihmisen näkökulmaan ja kokemukseen.

Sekä elokuvassa että kirjoissa ei-inhimilliset eläimet merkitsevät ihmisten ja porojen näkökulmasta myös vaaraa. Nogo-suvun Anikossa suden näkökulmasta kerrotut kappaleet osoittavat, kuinka inhimillisen ja ei-inhimillisen yhteiselo aiheuttaa välillä myös yhteentörmäyksiä ja tekee myös sudesta lukijan silmissä samaistuttavan toimijan. Tumajevin elokuvassa susi esiintyy vain vaaran elementtinä, jonka ulvonta kantautuu tundran lakeuksilta ja luo stereotyyppistä kuvaa nenetsileiriä ympäröivän perifeerisen seudun villiydestä ja hallitsemattomuudesta. Toisaalta susi toimii elokuvassa myös tundran maskuliinista järjestystä ylläpitä- 
vänä tekijänä: yksin tundralle lähteneen Savanen reki joutuu susilauman piirittämäksi, mutta paikalle rientänyt Aljoška pelastaa hänet. Kaiken kaikkiaan, vaikka elokuvassa hyödynnetään arktisen tundran ei-inhimillisiä eläimiä alueen ja sitä asuttavan alkuperäiskansan elämän kuvauksessa, nojaavat näiden esitykset alueen ulkopuolisten yhteisöjen konventionaaliseen kuvastoon arktisesta tundrasta sen sijaan, että pyrkisivät haastamaan tätä.

\section{Kaksi erilaista tundraa}

Arktinen tundra näyttelee olennaista osaa sekä Nerkagin 1970- ja 1990-luvuilla ilmestyneissä pienoisromaaneissa että niistä 2010-luvulla tehdyssä elokuva-adaptaatiossa, joskin teosten luomat representaatiot alueesta ovat vähintäänkin hyvin jännitteisessä suhteessa keskenään. Yksi alueen kuvausten välisistä eroista on ajankohta, johon teokset sijoittuvat ja joka määrittää alueen asemaa suhteessa muuhun maahan. Nerkagin 1970-luvulle sijoittuvassa Nogo-suvun Anikossa kyllä kuvataan alkuperäiskansan ja sen perifeerisen asuinalueen kohtaamia haasteita, mutta teoksessa esiintyy optimistisia ja toiveikkaita ääniä, jotka uskovat järjestelmän hyötyihin pitkällä aikavälillä. Neuvostoliiton hajoamisen jälkeinen taloudellisesti vaikea tilanne ja Venäjän arktisen alueen autioituminen näkyy puolestaan 1990-lukua kuvaavassa Valkeaa jäkälää leimaavassa lohduttomuudessa ja rapistumisessa. 2010-lukua kuvaavaan elokuvaan näitä pienoisromaanien aikakausiin liittyviä piirteitä ei ole tuotu, mutta niitä ei myöskään korvata 2010-luvulle tyypillisiä arktisen alueen ongelmia, kuten ilmastonmuutosta tai luonnonvarojen hyödyntämistä, käsittelevällä kuvastolla.

Suurin jännite pienoisromaanien ja elokuvan muodostamien tundran representaatioiden välillä pohjaa kuitenkin siihen, että teosten kuvaukset nojaavat erilaisiin kuvitteellisiin maantieteisiin. Tämä näkyy selvimmin siinä, kuinka erilaisena tundra teoksissa kuvataan. Nerkagin pienoisromaanien tundra on ennen kaikkea alkuperäiskansan eletty toimintaympäristö, joka kytkeytyy nenetsien historiaan ja suhteeseen alueen ei-inhimillisen luonnon kanssa. Tumajevin elokuvassa kuvaus alkuperäiskansan kotiseudusta on selvästi kytköksissä alueen ulkopuolelta nousevaan kulttuuriseen kuvastoon heijastaen sekä arktiseen alueeseen liitettyjä kliseitä että Venäjän 2000-luvun arktista diskurssia, jossa maan identiteettiä arktisena suurvaltana ylläpidetään korostamalla maan pohjoisten alueiden ja valtakeskusten välistä yhteyttä. Samalla Venäjän vaikutusta arktisella alueella vahvistavat representaatiot peittävät alleen pohjoisten alkuperäiskansojen ja näiden asuinalueiden välisestä yhteydestä kertovan kuvaston ja hämärtävät näin Venäjän alueella harjoittamaa asuttajakolonialistista politiikkaa.

Tämä ero heijastuu myös siihen, kuinka teoksissa käsitellään niiden keskeisiä kysymyksiä, periferian ja valtakeskusten välistä suhdetta sekä alkuperäiskansanuorten valintaa tundran ja kaupungin välillä. Alueiden välinen jännite, niiden välillä valitsemisesta aiheutuva sisäinen ristiriita ja seuraukset alkuperäiskansayhteisölle sekä sisäoppilaitosten ja kaupunkien edustama juurilta repimisen tematiikka muodostavat olennaisen osan Nerkagin teoksissa kuvattua nenetsien kuvitteellista maantiedettä. Nämä kysymykset eivät ole mustavalkoisia ja jokaiseen tehtyyn päätökseen liittyy kipeitä uhrauksia. Tumajevin elokuvaan tämä kompleksisuus ei ole siirtynyt. Vaikka elokuvassa on pyrkimys kuvata alkuperäiskansalle tärkeää kysymystä, käsitellään aihetta tavalla, joka vastaa alueen ulkopuolelta tulevan katsojan odotuksiin ja vahvistaa jo olemassa olevia stereotyyppisiä käsityksiä arktisesta tundrasta. Tämä stereotypioihin palaaminen johtaa väistämättä ongelman yksinkertaistamiseen, josta selkeimpänä esimerkkinä toimii sen redusoituminen latteaksi kolmiodraamaksi. Kompleksisen ja traagisen ongelman 
väkinäinen yksinkertaistaminen johtaa kuitenkin todennäköisesti tahattomaan lopputulokseen. Elokuvan kliimaksiksi tarkoitettu kuvaus päähenkilön tekemästä "valinnasta" latistuu itsenäisen päätöksen sijaan olosuhteiden pakosta aiheutuvaksi kohtaloon tyytymiseksi ja esittää täten alkuperäiskansanuorten halun jäädä omalle kotiseudulleen varsin surullisessa valossa.

\section{Viitteet}

1 Artikkeli on kirjoitettu Koneen Säätiön projektin "Pohjoiset naapurit. Luonto ja ihminen Venäjän arktisen alueen kirjallisuudessa" (projektinumero 201803242) rahoituksella.

2 Termin "jälkikolonialistinen" tai "postkolonialistinen" määrittelystä tarkemmin ks. Loomba 2015, $28-39$.

3 Artikkelissa esiintyvät pienoisromaanien ja elokuvarepliikkien käännökset ovat omiani.

4 Maalitsa on nenetsien käyttämä poronnahkainen päällysvaate.

5 Kuoleman ja sairauksien jumaluus nenetsiperinteessä.

6 Tavassa, jolla Nerkagin romaanit kuvaavat tundraa monien erilajisten toimijoiden verkostona, voi nähdä yhtymäkohtia posthumanistiseen ja uusmaterialistiseen ajatteluun (ks. esim. Braidotti 2013; Iovino \& Oppermann 2014). Tämän artikkelin puitteissa kyseisten näkökulmien esittely jäisi kuitenkin niiden ansaitsemaa huomiota suppeammaksi, mutta syvennyn Nerkagin romaanien posthumanistisiin luentamahdollisuuksiin tekeillä olevassa väitöskirjatutkimuksessani.

\section{Lähteet}

Anderson, Benedict (1991), Imagined Communities. Verso: London.

Appadurai, Arjun (1996), Modernity at Large: Cultural Dimensions of Globalization. Minneapolis: University of Minnesota Press.

Basso, Keith (1996), Wisdom Sits in Places: Notes on a Western Apache Landscapes. - Senses of Place. Eds. Steven Feld and Keith H. Basso. Santa Fe: School of American Research Press, 53-90.

Belyj jagel (2014), Belyj jagel - elokuva. Ohjaaja Vladimir Tumajev. Käsikirjoittajat Valeri Bakirov \& Savva Minajev. Tuotantoyhtiö Mosfilm.

Bloch, Alexia (2004), Red Ties and Residential Schools: Indigenous Siberians in a Post-Soviet State. Philadelphia: University of Pennysylvania Press.

Bloom, Lisa (1993), Gender on Ice: American Ideologies of Polar Expeditions. Minneapolis: University of Minnesota Press.

Boliachevets, Lilia and Sablin, Ivan (2016), The Second and the Fourth World: Critique of Communism and Colonialism in Contemporary North Asian Literature. Ab Imperio 2: 385-425. https:// doi.org/10.1353/imp.2016.0038

Braidotti, Rosi (2013), The Posthuman. Cambridge: Polity Press.

Bruno, Andy (2016), The Nature of Soviet Power: An Arctic Environmental History. New York: Cambridge University Press. 
Bruno, Giuliana (2002), Atlas of Emotion: Journeys in Art, Architecture, and Film. New York: Verso. Castro, Teresa (2009), Cinema's Mapping Impulse: Questioning Visual Culture. - The Cartographic Journal 46:1, 9-15.

Certeau, Michel de (1984), The Practice of Everyday Life. Trans. by Steven Rendall. Berkeley: University of California Press.

Eglinger, Hanna (2010), “Traces against Time's Erosion": The Polar Explorer between Documentation and Projection. - Arctic Discourses. Ed: Ryall, Anka, Waerp, Henning Howlid \& Schimanski, Johan. Newcastle upon Tyne: Cambridge Scholars Publishing, 2-18.

Forsyth, James (1992), A History of the Peoples of Siberia: Russia's North-Asian Colony 1581-1990. Cambridge: Cambridge University Press.

Germond-Duret, Celine (2016), Tradition and modernity: an obsolete dichotomy? Binary thinking, indigenous peoples and normalisation. -Third World Quarterly, 37:9, 1537-1558. https://doi.org $/ 10.1080 / 01436597.2015 .1135396$

Goeman, Mishuana (2013), Mark My Words: Native Women Mapping Our Nations. Minneapolis: University of Minnesota Press.

Golovnev, A. V. (1995), Govorjaštšie kultury: tradicii samodijtsev i ugrov. Jekaterinburg: UrO RAN.

Hallowell, Irving (1960), Ojibwa Ontology, Behavior and World View. -Culture in History. Ed: S. Diamond. New York: Columbia University Press, 19-52.

Homitš, L. V. (1966), Nentsy: Istoriko-etnografitšeskie otšerki. Moskva: Nauka.

Hønneland, Geir (2016), Russia and the Arctic: Environment, Identity and Foreign Policy. London: I. B. Tauris.

Hutcheon, Linda (2013), A Theory of Adaptation. Second Edition. London: Routledge.

Huusko, Svetlana (2018), Evenki Adolescents' Identities: Negotiating the Modern and the Traditional in Educational Settings. - Sibirica 17:1, 36-62. https://doi.org/10.3167/sib.2018.170104

Iovino, Serenella \& Oppermann, Serpil (2014), Material Ecocriticism. Bloomington: Indiana University Press.

Jazeel, Tariq (2019), Postcolonialism. London: Routledge.

Jersild, Austin (2002), Orientalism and Empire: North Caucasus Mountain Peoples and the Georgian Frontier, 1845-1917. Montreal: McGill-Queen's University Press.

Knight, Nathaniel (2000). Grigor'ev in Orenburg, 1851-1862: Russian Orientalism in the Service of Empire? - Slavic Review 59:1, 74-100. https://doi.org/10.2307/2696905

Laruelle, Marlene (2015), Russia's Arctic Strategies and the Future of the Far North. London: Routledge.

Layton, Susan (1994), Russian Literature and Empire: Conquest of the Caucasus from Pushkin to Tolstoy. Cambridge: Cambridge University Press.

Ljarskaja, Jelena (2016), "U nih že vse ne kak u ljudei...": Nekotorye stereotipnye predstavlenija pedagogov Jamalo-Nenetskogo okruga o tundrovikah. - Antropologitšeski forum 5, 242-258.

Lefebvre, Henri (1991), The Production of Space. Transl. by Donald Nicholson-Smith. Oxford: Blackwell.

Loomba, Ania (2015), Colonialism/Postcolonialism. Third Edition. London: Routledge.

McCannon, John (1998), Red Arctic: Polar Exploration and the Myth of the North in the Soviet Union, 1932-1939. New York: Oxford University Press.

McCorristine, Shane (2018). The Spectral Arctic: A History of Dreams and Ghosts in Polar Exploration. London: UCL Press.

Nerkagi, Anna (1996a), Belyj jagel. - Moltšaštši. Povesti. Tjumen: Soft Dizain, 11-118.

Nerkagi, Anna (1996b), Aniko iz roda Nogo. - Moltšaštši. Povesti. Tjumen: Soft Dizain, 307-403.

Radcliffe, Sarah A. (1996), Imaginative Geographies, Postcolonialism, and National Identities: Contemporary Discourses of the Nation in Ecuador. - Ecumene 3:1, 23-42.

Reed, Beatrice (2018), From Anthropomorphism to Ecomorphism: Figurative Language in Tarjei Vesaas' Fuglane and Stina Aronson's Hiltom himlen. - Nordic Narratives of Nature and the Environment. Ecocritical Approaches to Northern European Literatures and Cultures. Ed: Reinhard Hennig, Anna-Karin Jonasson \& Peter Degerman. Lanham. London: Lexington Books, 117-136.

Ridanpää, Juha (2017), Imaginative regions. -The Routledge Handbook of Literature and Space. Ed. Tally, Robert T. London: Routledge, 256-266. 
Ryall, Anka, Schimanski, Johan \& Waerp Henning Howlid (2010), Arctic Discourses: An Introduction. - Arctic Discourses. Ed: Ryall, Anka, Schimanski, Johan \& Waerp, Henning Howlid. Newcastle upon Tyne: Cambridge Scholars Publishing, ix-xxii.

Said, Edward (2011), Orientalismi. Suom. Kati Pitkänen. Helsinki: Gaudeamus.

Schimmelpenninck van der Oye, David (2010), Russian Orientalism: Asia in the Russian Mind from Peter the Great to the Emigration. New Haven: Yale University Press.

Slezkine, Yuri (1994), Arctic Mirrors: Russia and the Small Peoples of the North. Ithaca: Cornell University Press.

Soja, Edward (1996), Thirdspace: Journeys to Los Angeles and Other Real-and-imagined Places. Cambridge: Blackwell.

Tally Jr., Robert T. (2013), Spatiality. London: Routledge.

Thornton, Thomas F. (2007), Being and Place among the Tlingit. Seattle: University of Washington Press.

Turoma, Sanna (2013), Imperiia Re/Constructed: Narratives of Sapce and Nation in 1960s Soviet Russian Culture. - Empire De/Centered: New Spatial Histories of Russian and the Soviet Union. Ed: Sanna Turoma \& Maxim Waldstein. Surrey and Burlington: Ashgate, 239-256.

Turoma, Sanna \& Waldstein, Maxim (2013), Introduction: Empire and Space: Russian and the Soviet Union in Focus. -Empire De/Centered. New Spatial Histories of Russia and the Soviet Union. Ed: Sanna Turoma \& Maxim Waldstein. Surrey and Burlington: Ashgate, 1-28.

Ulturgasheva, Olga (2012), Narrating the Future in Siberia: Childhood, Adolescence and Autobiography among the Eveny. New York: Bergham Books.

Urfu (2020), Filologi vuza vydvinuli Annu Nerkagi na Nobelevskuju premiju po literature. 19.2.2020. Uralski Federalny universitet, https://urfu.ru/ru/news/30809/ (Tarkistettu 28.10.2020.)

Vitebsky, Piers (2005), The Reindeer People: Living with Animals and Spirits in Siberia. Boston: Houghton Mifflin Company.

Warf, Barney \& Arias, Santa (eds.) (2009), The Spatial Turn. Interdisciplinary Perspectives. London: Routledge.

Widdis, Emma (2004), Russia as Space. -National Identity in Russian Culture: An Introduction. Ed by Simon Franklin \& Emma Widdis. Cambridge: Cambridge University Press, 30-49.

Willerslev, Rane (2007), Soul Hunters: Hunting, Animism, and Personhood among the Siberian Yukaghirs. Berkeley: University of California Press.

Wolfe, Patrick (2006), Settler Colonialism and the Elimination of the Native. Journal of Genocide Research 8:4, 387-409.

Ziemer, Ulrike (2011), Ethnic Belonging, Gender, and Cultural Practices: Youth Identities in Contemporary Russia. Stuttgart: Ibidem Verlag. 